\title{
MRI of toxic leukoencephalopathy syndrome associated with methylenedioxymethamphetamine
}

Figure $\quad$ MRI of MDMA-induced leukoencephalopathy

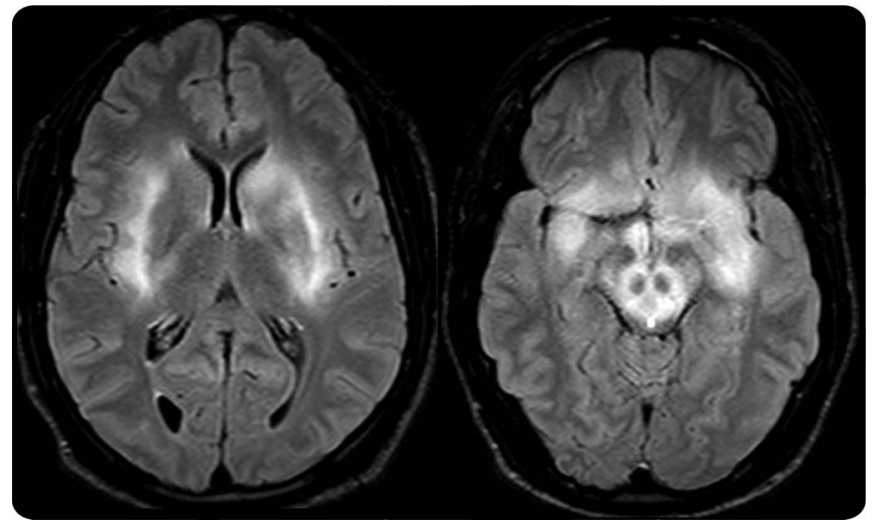

Axial fluid-attenuated inversion recovery images show diffuse hyperintensity predominantly involving the midbrain, insulae, and basal ganglia bilaterally.

A 17-year-old boy presented with headaches, altered mental status, and double vision 2 days after ingestion of "molly" pills (methylenedioxymethamphetamine [MDMA], ecstasy), which was detected on urine toxicology. Lumbar puncture yielded CSF with mild lymphocytosis and elevated protein. Rheumatologic, infectious, and other toxicologic workup had negative results. MRI of the brain showed diffuse signal abnormality in the midbrain, bilateral insulae, and basal ganglia bilaterally (figure). Leukoencephalopathy related to MDMA use is uncommon and believed to result from serotonergic neuronal damage and myelin damage from oxidative stress. ${ }^{1}$ Individual susceptibility may be related to abnormalities in the demethylation of debrisoquine hydroxylase. ${ }^{2}$

Daniel Thomas Ginat, $M D$, MS

From the University of Chicago, IL.

Study funding: No targeted funding reported.

Disclosure: The author reports no disclosures relevant to the manuscript. Go to Neurology.org for full disclosures.

Correspondence to Dr. Ginat: ginatd01@gmail.com

1. Sprague JE, Everman SL, Nichols DE. An integrated hypothesis for the serotonergic axonal loss induced by 3,4-methylenedioxymethamphetamine. Neurotoxicology 1998;19:427-441.

2. Tucker GT, Lennard MS, Ellis SW, et al. The demethylenation of methylenedioxymethamphetamine ("ecstasy") by debrisoquine hydroxylase (CYP2D6). Biochem Pharmacol 1994;47:1151-1156. 


\section{Neurology}

\section{MRI of toxic leukoencephalopathy syndrome associated with methylenedioxymethamphetamine \\ Daniel Thomas Ginat \\ Neurology 2015;84;757 \\ DOI 10.1212/WNL.0000000000001271}

This information is current as of February 16, 2015

\section{Updated Information \& Services}

References

Subspecialty Collections

Permissions \& Licensing

Reprints including high resolution figures, can be found at: http://n.neurology.org/content/84/7/757.full

This article cites 2 articles, 0 of which you can access for free at: http://n.neurology.org/content/84/7/757.full\#ref-list-1

This article, along with others on similar topics, appears in the following collection(s):

\section{All Clinical Neurology}

http://n.neurology.org/cgi/collection/all_clinical_neurology MRI

http://n.neurology.org/cgi/collection/mri

Information about reproducing this article in parts (figures,tables) or in its entirety can be found online at:

http://www.neurology.org/about/about_the_journal\#permissions

Information about ordering reprints can be found online:

http://n.neurology.org/subscribers/advertise

Neurology ${ }^{\circledR}$ is the official journal of the American Academy of Neurology. Published continuously since 1951 , it is now a weekly with 48 issues per year. Copyright @ 2015 American Academy of Neurology. All rights reserved. Print ISSN: 0028-3878. Online ISSN: 1526-632X.

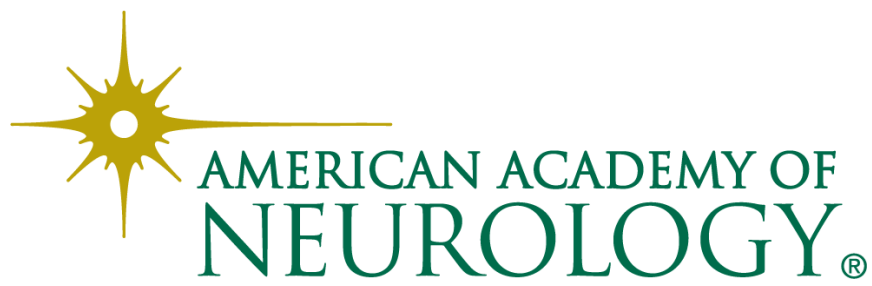

